\title{
Workplace Relations, Social Dialogue and Political Milieu in Nigeria
}

\author{
Sola Fajana \\ Department of Industrial Relations and Personnel Management \\ University of Lagos \\ Akoka, Yaba, Lagos, Nigeria \\ Tel: +23-480-6624-8214Ｅ-mail: solafajana@yahoo.com \\ Oluseyi A. Shadare (Corresponding author) \\ Department of Industrial Relations and Personnel Management \\ University of Lagos \\ Akoka, Yaba, Lagos, Nigeria \\ Tel: +23-480-3304-9507_E-mail: seyidare2001@yahoo.co.uk
}

Received: April 20, 2011

doi:10.5430/ijba.v3n1p75
Accepted: May 17, 2011 Published: January 5, 2012

URL: http://dx.doi.org/10.5430/ijba.v3n1p75

\begin{abstract}
Harmonious and stable labour-management relations are sine qua non to the development process in Nigeria. For economic and social stability, Nigeria needs to sustain the existing democracy, encourage social dialogue with a view to coping with conflictual issues nationwide. It is against this backdrop that this paper seeks to examine social dialogue as a set of roles for trade unions, and the degree to which this function is enabled or constrained by the dynamics of the political environment in Nigeria. To achieve this objective the authors adopted the qualitative research method. Secondary data such as collective agreements, newspapers reports and official state records were used and supplemented with in-depth interviews with key union representatives and employers' organizations. The authors outline essential elements for social dialogue and how it can contribute to healthy labour-management relations. The authors addressed the positive contributions that social dialogue can make towards minimising open expression of conflicts with the negative consequences on the tripartite social partners, as well as the impacts of political milieu on the effectiveness of trade unions and by extension social dialogue in Nigeria.
\end{abstract}

Keywords: Work Relations, Social Dialogue, Political Milieu, Conflict, Trade Unions

\section{Introduction}

Work place relations has been turbulent in recent times arising from conflictual situations in the world of work. In the employment relationship, the interests of employers represented by management and the employees represented by the union have been diametrically opposed. This has historically been the cause of conflict in industry. Social dialogue is a process of exchanging information and viewpoints that may ultimately facilitate harmonious labour relations. It may be tripartite or bipartite. In its tripartite form, dialogue involves co-operation among government, employers' organisations and workers' organisations in formulating or implementing labour, social or economic policy (ILO, 2002). The bipartite relationship involves employers and trade unions where the government acts as a silent partner by setting the parameters for the parties' interaction. Both forms may be purely advisory to the government or may involve negotiations leading to agreements. The relevant ILO instruments concerning social dialogue are the Consultation (Industrial and National Levels) Recommendation, 1960 (No. 113).

Productivity-enhancing dialogue requires continual dissemination of management's labour policy to workers. Yet, managements sometimes feel reluctant to release information to the unions because information (e.g. accounting reports) may be misused. The unions on the other hand, often claim they are entitled to know their employers' general and human resource management policies. Thus, employees often express the desire to know what is happening, and the extent to which their jobs are affected. There has been no global concensus as to what policies should be made available 
to unions and in what areas of management decisions the unions should be involved. The lack of consensus is accounted for by:

- Differences in the level of growth and affordability of firms;

- Absence of an industry-wide structure bringing all employers together (eg oil employers are still unorganised);

- Peculiarities of the nature of business - e.g., some are in exploration, production, refinery, petrochemical and marketing, manufacturing and service - with distinct operational peculiarities and conditions.

The aim of this paper is to examine social dialogue as a set of roles for the social partners in the employment relations, and the degree to which social dialogue is enabled or constrained by the dynamics of the political environment in Nigeria. Most of the reviewed evidence pertains to the oil sector and supplemented with further evidence from other industries To achieve this objective the authors adopted the qualitative research method. Secondary data such as collective agreements, newspapers reports and official state records were used and supplemented with in-depth interviews with key union representatives and employers' organizations.

\section{Theoretical and Conceptual Framework}

This study leans on the pluralist or pluralistic theory of employment/industrial relations and the contingency theory. The pluralist or the pluralistic frame of reference is synonymous with the conflict theory which is also credited to Fox (1966). This theory views the organisation as coalescence of sectional groups with different values, interests and objectives. Thus, employees have different values and aspirations from those of management, and these values and aspirations are always in conflict with those of management. Pluralist theorists argue that conflict is inevitable, rational, functional and normal situation in organisations, which is resolved through compromise and agreement, collective bargaining or social dialogue. Rose (2008) posits that the pluralist perspective would seem to be much more relevant than the unitary perspective in the analysis of employment/industrial relations in many large organisations and congruent with developments in contemporary society.

The contingency theory holds the view that employment/industrial relation as well as human resource management is influenced by the organization's environment and circumstances (Legge, 1978; as cited in Armstrong, 2009). Thus work relations and social dialogue cannot exist in a vacuum but within an operating milieu or environment of which the political milieu is of paramount importance.

Various policies are employed by management to ensure good employment/ industrial relations between workers and their employers. Nevertheless, matters generally covered include corporate performance and plans for structural changes like mergers and acquisitions, redundancy arising from changes in the organisation environment. Others are the job requirements of an employee and the reporting system, disciplinary rules, social and welfare facilities, safety rules and suggestion schemes. More details are revealed in adopted modes of communication.

\subsection{Internal Communication}

Most employers support effective interactions with their employees, whether unionised or not. Several means are available and new ones are evolving for serving social dialogue in industry. They include:

- Maintenance of industrial intranet connectivity. This innovation, which includes email facilities, is very common with the big players in industry and service. Workers including those at remote locations are given access to company computers or cyber cafes serviced by contractors for the purpose of letting workers have access and to pass information to their superiors and colleagues. This is convenient and cheap.

- Publication of house journals and magazines. This is a traditional method of industrial communication. They carry information on the personal circumstances of staff and on the social events in the organization. Examples are news on staff wedding, naming ceremonies, leave, promotion and advancement, termination, etc. Bulletins, notice boards, newsletters, and house journals are freely used for disseminating such information

- Adoption of an open-door policy. Workers are now encouraged to come forward as individuals and in groups for the purpose of contributing their ideas in the management of firms. The firms put all relevant information at the disposal of the employees who would respond by making suggestions for improvement.

- The use of suggestion schemes or suggestion box

- Involvement in decision-making and management role. Employee involvement and participation is usually encouraged in joint consultation, which will be discussed in some details in subsequent section. 
- In the oil sector, local contractors are encouraged to participate in decision-making thereby getting the community and contract employees involved in the management of business. In the absence of this arrangement, contract staff would have very little or no voice in the management of the parent companies.

\subsection{Joint Consultation}

Joint consultation is a two-way communication process employed for resolving conflict arising from issues of mutual interest. Rather than merely inform, here management goes out of its way to seek the views of the staff on management's plans for the introduction of changes. Workers' contributions are taken and may be used in decisions (Fajana, 2000). In the big firms, Joint Consultative Committees (JCCs) are usually organised on plant basis. They serve the following functions:

- Giving employees the prospect of improving policies through their submissions, making full use of staff expertise, ideas and innovations;

- Offering labour and management the opportunity to identify with and have a high opinion of each other's views and perceptions;

- Making available a forum where management and staff can swap over advice, opinions and ideas on all matters touching their joint and several interests in the workplace before or after decisions have been made;

- Providing a workable method of associating employees with the running of the business;

- Creating an unassailable safety valve and a two-way channel of communication between staff and management;

- Helping to foster co-operation between management and employees; and

- Improving the quality of decisions by using the knowledge and experience of those most affected by those judgements.

Based on the interview had with respondents, a key informant from an oil service contractor commented that periodic consultative meetings between management and union representatives and constant exchange of information at all levels are the adopted mechanisms for social dialogue. Methodologically, this mechanism is a sincere and unhindered discussion of all issues. The discussion and arguments are normally based on facts and respect for each side's feelings and aspiration. Conscious effort is made to ensure the implementation of all resolutions and understandings reached. This helps to eliminate distrust.

\subsection{Collective Bargaining}

Flanders defined collective bargaining (CB) as the "procedure by which wages and conditions of employment of workers are regulated by agreements between the workers' representatives and their employers. This conceptualization of CB is captured by investorwords.com (2007) as a method of negotiation in which employees use authorized union representatives to assist them. The $\mathrm{CB}$ process is internationally acclaimed as the legal instrument by which workers and management settle conflicts arising from employment contracts. In particular, the conventions and standards of the ILO are noticeable and instrumental. The result of the negotiation process is the signing of an agreement by both parties. CB thus exemplifies bipartite social dialogue. Collective bargaining in Nigeria is as old as the economic history of the nation. On account of special circumstances arising from learning from Western experiences during colonialism, trade unions and collective bargaining were introduced long before the country experienced its initial industrialization (Fajana, 2009).

Affordability continued to remain a big constraint against the readiness of employers to concede well deserved improvements that unions often ask for. Generally, bargaining has experienced considerable elevating policy pronouncements but less in terms of its seriousness and effectiveness in various industrial sectors. Nevertheless, the following reasons account for its current and possibly continued adoption in Nigerian industries:

Unilateral determination or awards by the employers might record short term acceptance, but they are not likely to be satisfying in the long run since employers may change their minds and workers may prefer lower rates that came out of collective negotiations that were characterised by more commitment. This position was maintained by the Nigeria Labour Congress (NLC) in its struggle to determine minimum wage for the country in the 1990s. The NLC indicated an endorsement for a lower but negotiated rate, and resisted unilateral offers (awards) made by the state.

\section{Movement for Decent Work and Pay}

A trend to which employers and trade unions in Nigeria had to respond positively is the wish of the International Labour Organisation for decent work and decent pay. The adopted strategy is to reference its conventions and standards for collective bargaining to ensure that workers have a fairer deal at work; that slavery working conditions are minimised. By guaranteeing the right to $\mathrm{CB}$, it was felt that workers pay would be equitable and just. In some industries CB has 
been recognised as inevitable. For instance in the Nigerian oil sector where the employers do not have serious singular body for regulating terms and conditions of employment, and even where there do not exist trade unions (as in the Central Bank, the Police and Armed Forces), informal arrangements are being utilised to regularly dialogue and use joint consultation for the purpose of determining terms and conditions of employment. This emerging trend would seem to be explained in the functional value of $\mathrm{CB}$ which has made it attractive to non-unionised work settings. The theoretical explanation would be that $\mathrm{CB}$ as a feature of industrial democracy is found compatible with open book management which emerged in the 1980s, although its effects seem to be waning in the 2000s. CB is also currently compatible with the economic reality of Nigeria, having emerged from the dualistic framework of a large public market sector to one of liberalisation via privatisation of public enterprises. CB had relatively thrived historically in the private sector, hence, a growing of that sector suggests greater rate of adoption of CB economy-wide, all other things being equal.

The informal sector operators often resist unionisation and CB by appealing to the relatively small size of their operations and the wish to retain control and cohesion among their workforce. Nevertheless, their choice of wage determination will affect the decency of work and pay. CB is fast emerging as the optimal option. The appeal of collective negotiation in reported cases in South Africa has been explained by observability from current adopters and the possibility of instalment trials. In a study of selected SMEs in Southern Africa (Fashoyin et al 2006) found that a number of SMEs have had trade unions for at least some period, while some were presently active. The ease with which firms choose to adopt and discontinue with unions is possibly explained by the trialability characteristics of CB institutions and processes in the informal sector (Rogers, 1983, Fajana 1991). Even if CB is not very active in the SMEs, other forms of labour-management cooperation are possible and flourishing.

\subsection{ILO and its Monitoring Role}

The role of the ILO in explaining the current high adoption rate of CB in Nigerian industries is to be appreciated. ILO monitoring reports have persuaded the Nigerian government to revisit its policy, and to set up amendments to the Trade Union Act in 2005, with the sole object of democratizing trade union and CB process. Faster adoption rates of CB have been encouraged in Nigeria by the positive adoption behaviour of very large firms, serving as models that are observable by other firms. Some multinational firms have served this model role for other employers creditably. These firms exert considerable positive impact on smaller organisations by making sure that the interests and capacity of smaller firms are considered in the CB process. To accommodate the capacity to pay among diverse firms, categorisations of some sorts, and ranges are instituted in national agreements, while company-specific rates are fixed at the domestic levels. Less inclusiveness would have been achieved if such capacity limitations have been ignored by organised employers in different trade groups in the Nigerian system of industrial relations. In the effect, smaller firms are encouraged to embrace collective negotiations. This approach is recommended for continuation in Nigerian industrial relations.

\subsection{Contractor's Forum}

An emerging system of business operations in this millenium is outsourcing which releases organisations to concentrate on their core activities while farming out their support services. To further social dialogue involving the social partners, new approaches are being crafted. The attempt here is to bring together companies, their contractors, the trade unions and other stakeholders to dialogue over issues of mutual interests. Thus, contractor's forum or variants of this, exists in several companies. In the specific case of Shell (SPDC), the forum expanded its consultative role to negotiate with the SPDC Service Contract Staff as represented by NUPENG National Secretariat. In this 'negotiation' facilitated by SPDC, all stakeholders (SPDC, NUPENG and SPDC Contractors) undertook to work together to ensure industrial peace and harmony; but NUPENG and PENGASSAN in SPDC agreed not to go on strike. This was in a communiqué issued at the end of the mediatory meeting by the Federal Ministry of Labour and Productivity involving the stakeholders at the conference room of the Labour Ministry on the $7^{\text {th }}$ of April 2004. The Forum was able to reach agreements on the issue of Direct Hire Term Contract in SPDC with regard to their membership in PENGASSAN. This helped to nip in the bud what might eventually have emerged as a serious dispute between the two unions in the oil sector.

\subsection{Community Relations Dialogues}

Interactions do take place between the leadership of the communities, especially in the Niger Delta, and the management of the oil firms. The trade union as an important stakeholder usually observes the proceedings sometimes providing critical inputs towards dousing youth restiveness. The agitation of the youths arises from the tampering with the ecology and hence economic environment and livelihood of the indigenes. The interest of the oil workers in participating in such dialogues stems from the concern over heath and security issues as community restiveness sometimes involve the arrests and killings of oil workers, Nigerian nationals and foreigners alike. 


\subsection{Phenomenal Mutual Benefits}

Dialogue instigates and sustains the co-operation of trade unions as a benefit to all parties. Against the backdrop of a mutual understanding of the need to partner with employers, workers and their representatives readily offer to assist the employers in achieving a competitive and profitable business. For instance, PENGASSAN has realised that, “... we are in a global world - a very dynamic world that requires the unions to go beyond the frontiers and make efforts to get involved in how the organisation is being managed and the various changes that are taking place in the organisation. So apart from industrial relations topics, issues concerning technology, the environment and the organisation are jointly discussed and agreed upon by both companies and representatives of the different trade unions (PENGASSAN, 2002). Unions now sponsor workshops and other training programmes in areas that would ordinarily be regarded as the functions or concerns of management. Consultations and other forms of social dialogue have always yielded benefits to workers in terms of:

- Respect for the talents of workers as recognised by their employers;

- Reciprocal or mutual respects on both sides;

- Assurance of peaceful determination of future conflicts;

- Enhanced salary allowances and favourable conditions of service;

- More job and income security;

- Job satisfaction, motivation and self fulfilment; and

- The emergence of a small group of worker aristocrats (privileged with a higher social status).

The foregoing accounts show that industrial harmony is heavily dependent on social dialogue. The effects of functional dialogue on the stakeholders include, in respect of workers and their collectivises (Fajana,2000): (i) Job, income satisfaction and heightened morale and productivity which further enhances compensation under a merit or performance based pay system; (ii) Avoidance of victimising reactions when employers are frustrated by open conflicts arising from unresolved worker demands; and (iv) Mutual benefits as a result of opportunity to review trends and fortunes in the business.

In respect of the employers, the following positive outcomes are noted: (i) Avoidance of costs which would be incurred if conflicts are left open to strikes and other industrial actions; (ii) Avoidance of Loss of goodwill, patronage, output, revenue and profits; (iii) Avoidance of Loss of executive time; and (iv) Avoidance of the decline of morale and productivity of employees which usually occur before, during and after industrial actions.

The state would also put at jeopardy national security, given the criticality of oil in the national economy and its potency for affecting international politics, unemployment, inflation, political instability, executive take-overs (coup d'états), and kindred problems. All these are minimised when social dialogue is allowed to thrive.

\section{Stakeholders' Role in the Promotion of Social Dialogue}

\subsection{The Role of the State}

The Nigerian State must inevitably play a significant role in the promotion of social dialogue in industry. This is because the state is a major employer as well as a 'neutral' observer. The state therefore makes available a multi-party mechanism for dialogue whenever issues arise that cannot be resolved bi-partite. This action is in conformity with ILO Recommendation 113, which Nigeria has ratified. Specifically, the recommendation stipulates that consultation and co-operation should aim at ensuring that the competent public authorities seek the views, advice and assistance of employers' and workers' organisations in an appropriate manner, in respect of such matters as:

- The preparation and implementation of laws and regulations affecting their interests;

- The establishment and functioning of national bodies, such as those responsible for the organisation of employment, vocational training and retraining, labour protection, industrial health and safety, productivity, social security and welfare; and

- The elaboration and implementation of plans of economic and social development.

The state also has a legislative role to play in meeting its social dialogue imperatives. The State institutes the National Labour Advisory Council as a tripartite structure for the formulation and review of industrial relations policies. It is also required that the bi-cameral National Assembly ought to provide a forum for national debates of laws in industrial relations. Consequently, the National Assembly did take over a number of critical issues in the oil sector, such as:

- privatization of state-owned oil firms; 
- the plight of those workers who may be adversely affected by privatisation; and

- $\quad$ other labour reform bills, some of which are currently being attended to by the legislators.

Although the National Assembly seems to be doing something for labour generally, it is expected that some of the contending issues would have been subjected to public hearings, traditional of most global democratic legislative institutions and processes. But this has not been the case in Nigeria. At the State and Local Government levels, very little or nothing can be done because labour issues are on the exclusive legislative list, indicating that only the Federal Government can commit the state on labour matters. Nevertheless, state governors and chairmen of local government councils do intervene in conflict situations. Given the cultural imperative of respecting elders and people in authority, conflicts that initially appeared intractable with the formal due process might just wither away at the intervention of a very influential personality, even though these people are not even envisaged in the formal disputes machinery.

\subsection{The Role of Trade Unions}

Advocacy is a form of intervention by declaring support for a cause usually undertaken by a group. Several unions have played this role with some success in Nigeia. In the case of the oil sector, PENGASSAN has assumed this role on behalf of Nigerian people and their social emancipation. PENGASSAN opens up the channel of communication and dialogue with the competent public authorities for the purpose of influencing public policy. The Association felt that by joining voices with other groups with the same convictions and values, sufficient pressure is being put on the government so that the issues will be discussed with the competent and relevant stakeholders affected for the ultimate benefits of all parties.

\section{Political Milieu and Social Dialogue}

Recent political developments in Nigeria have been amazing for employment/industrial relations and the management of human resources. Highly successful strikes were staged by the petroleum workers as an aftermath of the annulment of June 12 election result. The 1994 general strike gradually withered because the military regime struck back, dismissing the leadership of the NLC and two petroleum sector unions, as well as arresting several well-known labour leaders. As a result of the military crackdown on the unions and their leaders, the labour movement fell into confusion for several months. In October 1994, the union leaders called for support from the International Labour Movement, which was growing increasingly worried about the open abuse of trade union rights by the military government.

In addition to the strike in the petroleum sector, there were pockets of disruptive strikes by teachers, health workers, and state employees. These strikes not only mirrored the strife-ridden political climate, but culminated in repeated government failure to honour commitments to its workers. Government economic policies quickly infuriated the recurrent economic decline. Real income waned and purchasing power dropped, while many workers lost their jobs due to production cutbacks and downsizing, as well as other measures aimed at restructuring work organizations. Teachers were particularly dismayed by disintegrating school system and the lack of a decent pay, while other public sector employees demanded that the government put into practice "relief packages" to help cope with biting inflation. Often, strikes were protests over the non-implementation of previous agreements. In the case of Academic Staff Union of Universities, for example, the government did not faithfully honour a 1992 agreement with the union. This led to a six-month strike action in 1994, with a nine-month repeat in 1996 on the same set of issues. Towards the end of the transition programme set up by Abacha, a strong movement that canvassed nation-wide rallies for his self-succession in office. Pro-democracy and human rights groups equally resisted this action across the country. This development seems to have dampened the hope of some Nigerian workers for honest and successful democratic governance in the future. Certainly, orientations at work must have been somewhat altered as a result of psychic modifications of the citizenry. Incidentally, General Abacha died in 1998, and his successor started a programme of reconciliation with the hope of encouraging the pro-democracy groups to play credible role in the task of rebuilding the country. This process was going on when Chief M. K. O. Abiola also died ostensibly of heart attack in prison.

The effect of political uncertainties in Nigerian workplaces is possibly an indirect one. In the specific case of the banks, as patronage by depositors took low ebb because of the changes in depositors' attitude, bank cash assets dwindled and thus, some of the distress encountered towards the early 2000s can be explained. Against this backdrop, the welfare of bank workers may be affected since the fortune of the bank employer is partly a determinant of staff welfare. For the rest of the economy, workers continue to suffer the uncertainties of job insecurity, poor living conditions and general stress and tension with deleterious effects on their health. On 29 May 1999, Nigeria managed to establish the Fourth Democratic Republic with Retired General Olusegun Obasanjo as a democratically elected President. Visibly some gains of democracy filtered into workplaces and the nation in the form of freedom of association and freedom of speech, but certainly a lot more still remained outstanding in the areas of legislative responsibility, and optimal macro-economic 
management from which desirable effects can spill over to workers' welfare. Characteristically, the political developments of the 1990s have remained sustained and invigorated.

By 2009, it became apparent that political developments in Nigeria do affect the psyche and orientation of workers. Individuals engage in social comparisons that ultimately led to assessments of inequity. In the outcome, workers who see politicians and military elité as improperly and inequitably advantaged in the allocation of national resources do vent their discontent on their workplaces via reduced morale and productivity as well as increased proneness to sabotage, or other measures that would seem to balance the observed inequity (Anifowose \& Babawale 2003). Against the backdrop of a milieu such as described, a number of issues emerge which contrain or challenge trade unionism and social dialogue. These are:

- Corruption: Nigeria's corruption profile scores and index are on the upward trend since 2000 (See appendix 1).

- Expensive running of state institutions

- Dysfunctional federalism

- Absence of well established political parties (system)

- Legislative incompetence

Coupled with a high incidence of corruption among the elites andthe perception of inequity experienced by workers, is the oversized expense sheet of running the agencies of the governments at all levels. For instance, official figures show that N29 million is approxinately the annual salary and allowances of each minister; 28 million naira is paid to each of the 109 senators in a year; N22 million is paid to each member of the house of representatives in a year; N1.4 billion is the estimated total payment to presidential aides in emoluments in a year and N593 billion is the total yearly payment to council chairmane/women and councillors in the nations 774 LGAs.

Also, N36 billion is the total salary of house of assembly members across the 36 states and N1.3 trillion naira is the estimated annual salaries allowances and fringe benefits of the nation's political office holders at all tiers of government.(This day, 2009). The government at the centre continues to exert extreme dominance on the overall system, making Nigeria's system of federalism to be dyfunctional. As the other stakeholders perceive the centre as the locus of power over decisions of macro character, extreme pressure is exercised at that level by the trade union centres operating in concert with the general civil society, whether organised or not. Consequently, requests for dialogue activities at the macro level have always been made by the national unions and carried to the federal government. State and local governments have received far less requests for dialogue activities.

Furthermore, Nigeria's political system easily lends itself to dominance by a few individuals on account of the pursuit of personal and individualistic interests at the expense of the social good. Although experts may attempt to label the current experiment at our political governance, to the uninitiated it would appear that the emerging system is peculiar crying for its own unique name. I suggest primitive accumulationism. The legislature in all political systems, ancient or modern, have always remained critical, playing the necessary oversight (internal check) functions (Oyelowo, 2007) However, the legislature seems to have failed in the discharge of the foregoing traditional functions. The lack of legislative capacity and competence is traceable to the general decay of socio-cultural values. Consequently, the legislature is not better than, in fact competes with, the executive arm of government in the promotion of expensive governance, lack of speed in the discharge of constitutional duties, failure to adopt the right methods, and the misplacement of priorities. For instance, the matter of the review of Nigerian labour laws which had been placed before the National Assembly has remained unattended over the last three years, whereas laws vindictively targetted at individual 'enemies', sponsored by the executive, are rushed through and passed into law. The effectiveness of Nigerian trade unions may have been limited by a rather unconducive political environment, as dictated by the incompetence of the legislature, a dysfunctional federalism and other explored reasons. Rather than remain encumbered without remedy, unions have taken some commendable measures. At the initiative of the unions, some advocacy has turned up also as a form of dialogue for collectively influencing state policies.

\section{Concluding Remarks}

Aside from traditional and evolving techniques of communication, including electronic, house publications, open door policies, and opportunities to participate in decision-making, joint consultation remains the most visible and the most significant form of communication in Nigerian industries. It enables the employer to achieve co-operation and organisational effectiveness, and the workers are able to advance the object of their unionisation, i.e., improvements in the terms and conditions of employment. Dialogue is a natural and socially acceptable way of interacting in the workplace, especially for taking decisions over issues of mutual and divergent interests. The employer and employees 
engage in a bi-partite relationship considering issues such as lunch and or refreshments / meals, trends in the business etc. Under the bipartite arrangements, joint consultation, collective bargaining, contractors forum and community-relations dialogues may be significant. Social dialogue has positive impact on industrial relations, especially on the two parties, employers and employees who deepens mutual respect in the process, and who dwelling under the experience and faith of previous practice is assured of future peaceful relations. In the peculiar case of contract and expatriate workers who may have been rendered very inactive in trade unionism in Nigeria, informal arrangements do exist for serving the social dialogue objective, thereby giving contract staff a feeling of belonging with their parent companies.

At the macro level, tripartite social dialogue is expected to provide the framework for dealing with issues that have general applications across all industries and all levels of goverance. State intervention at this level is to put all actors on a minimum platform, below which none of them should fall. The State, as an interested arbiter, intervenes at will, sets up a National Advisory Council and creates a public hearing forum at the National Assembly, all for social contestation. This explains the frustration of the trade unions who are sometimes forced to pursue dialogue in forms that are somewhat unconventional, to the mutual disadvantage of all the social partners. It is recommended that all social partners should increase their capacities for effective social dialogue on account of the received contemporary turbulence in the political environment.

\section{References}

Anifowose, R. \& Babawale, T. (2003). 2003 Elections And Democratic Consolidation In Nigeria. Lagos: Friedrich Ebert Stiftung, Lagos Office

Armstrong, M. (2009). Armstrong's Handbook of Human Resource Management Practice. (11 $1^{\text {th }}$ ed.). U.K: Kogan Page Ltd.

Ekeanyanwu, L. (2006). "Women to the Rescue in the Fight against Corrupton: Case Study of Nigeria”. Paper Presented at the 12th IACC, Guatemala, November.

Fajana, S. (2009). “Industrial Relations and Collective Bargaining Trends in Nigeria”. An ILO Commissioned Research Project. Geneva

Fajana, S. (1991) “Ascriptive Influences on Pay and Employment Conditions: A Survey of British Multinationals and Indigenous Employers in Nigeria. International Journal of Human resource Management. Vol.2, No.3 pp 345-358. http://dx.doi.org/10.1080/09585199100000072

Fajana, S. (2000). Industrial Relations in Nigeria: Theory and Features ( $2^{\text {nd }}$ ed.). Lagos: Labofin and Company.

Fashoyin T., Sims E \& Tolentino A., (2006) Labour- Management Cooperation in SMEs: Forms and Factors. International labour Office, Geneva.

Fox, A. (1966). Industrial Sociology and Industrial Relations. Royal Commission Research Paper N0. 3. London: HMSO

ILO (2002). The Promotion of Good Industrial Relations in Oil and Gas Production and Oil Refining. Geneva

Interview with informant from Halliburton, July 2004

Investorwords.com (2007)

Oyelowo, O. (2007). "Constitutionalism and the Oversight Functions of the Legislature in Nigeria”. Draft Paper Presented At African Network of Constitutional Law Conference on Fostering Constitutionalism in Africa Nairobi PENGASSAN INFO, 2002, Vol. 1 NO 2, p.20

Rogers E.M. (1983) Diffusion of Innovations. ( $3^{\text {rd }}$ ed) New York: Free Press

Rose, E.D. (2008). Employment Relations. ( $3^{\text {rd }}$ ed.). London: Pearson Education Ltd

This Day (2009). “Legislators, 36 Governors Okay Pay Cuts.” Friday 20 March. 
Table 1. Nigeria Corruption Index, 2000 - 2006

\begin{tabular}{|c|c|c|}
\hline Year & CPI RANKING & CPI SCORE \\
\hline 2000 & $90 / 90$ & 1.2 \\
\hline 2001 & $90 / 91$ & 1.0 \\
\hline 2002 & $101 / 102$ & 1.6 \\
\hline 2003 & $132 / 133$ & 1.4 \\
\hline 2004 & $144 / 146$ & 1.6 \\
\hline 2005 & $152 / 158$ & 1.9 \\
\hline 2006 & $143 / 163$ & 2.0 \\
\hline
\end{tabular}

Source: Ekeanyanwu (2006). 